\title{
Short-term effects of particulate matter constituents on daily hospitalizations and mortality in five South-European cities: Results from the MED-PARTICLES project
}

\author{
Xavier Basagaña a,b,c,*,1, Bénédicte Jacquemin a,d,e,1, Angeliki Karanasiou ${ }^{\mathrm{f}}$, Bart Ostro ${ }^{\mathrm{a}, \mathrm{g}}$, Xavier Querol ${ }^{\mathrm{f}}$, \\ David Agis $^{\text {a,b,c }}$, Ester Alessandrini ${ }^{\text {h }}$, Juan Alguacil c,i, Begoña Artiñano ${ }^{\mathrm{j}, \mathrm{k}}$, Maria Catrambone ${ }^{\mathrm{l}}$, \\ Jesús D. de la Rosa ${ }^{\mathrm{m}}$, Julio Díaz ${ }^{\mathrm{n}}$, Annunziata Faustini ${ }^{\mathrm{h}}$, Silvia Ferrari ${ }^{\mathrm{o}}$, Francesco Forastiere ${ }^{\mathrm{h}}$, \\ Klea Katsouyanni ${ }^{\mathrm{p}}$, Cristina Linares $^{\mathrm{c}, \mathrm{n}}{ }$, Cinzia Perrino ${ }^{\mathrm{l}}$, Andrea Ranzi ${ }^{\circ}$, Isabella Ricciardelli ${ }^{\circ}$, Evangelia Samoli ${ }^{\mathrm{p}}$, \\ Stefano Zauli-Sajani ${ }^{\circ}$, Jordi Sunyer ${ }^{\text {a,b,c,q }}$, Massimo Stafoggia ${ }^{h}$, on behalf of the MED-PARTICLES Study group ${ }^{2}$ \\ a Centre for Research in Environmental Epidemiology (CREAL), C/Doctor Aiguader 88, 08003 Barcelona, Spain \\ ${ }^{\mathrm{b}}$ Universitat Pompeu Fabra (UPF), C/Doctor Aiguader 88, 08003 Barcelona, Spain \\ c CIBER Epidemiología y Salud Pública (CIBERESP), C/Doctor Aiguader 88, 08003 Barcelona, Spain \\ d INSERM U1018, CESP-Centre for Research in Epidemiology and Population Health, UMRS U1018, Respiratory and Environmental Epidemiology Team, 16 Avenue Paul Vaillant Couturier, \\ 94807 Villejuif, France \\ e University Paris Sud, 16 Avenue Paul Vaillant Couturier, 94807, Villejuif, France \\ ${ }^{\mathrm{f}}$ Institute of Environmental Assessment and Water Research (IDAEA-CSIC), C/Jordi Girona 18-26, 08034 Barcelona, Spain \\ ${ }^{g}$ Air Pollution Epidemiology Section, Office of Environmental Health Hazard Assessment, California Environmental Protection Agency, 1515 Clay St 16 th floor, 94612 Oakland, CA, USA \\ h Department of Epidemiology, Lazio Region Health Service, Via di Santa Costanza 53, 00198 Rome, Italy \\ i Center of Research on Environmental Health (CYSMA), University of Huelva, Campus de El Carmen, 21007 Huelva, Spain \\ j Departamento de Medio Ambiente, CIEMAT, C/Complutense 40, 28040 Madrid, Spain \\ k CSIC-IDAEA/CIEMAT Associate Unit on Atmospheric Pollution, Spain \\ ${ }^{1}$ C.N.R. Institute of Atmospheric Pollution Research, Via Salaria Km 29, 300 Montelibretti, Rome, Italy \\ m Associate Unit CSIC-University of Huelva "Atmospheric Pollution", Centre of Research of Sustainable Chemistry (CIQSO), Campus of Excellence CEIA3, University of Huelva, \\ Edificio Robert H Grubbs, Campus de El Carmen, 21007 Huelva, Spain \\ ${ }^{n}$ National School of Public Health, Carlos III Health Institute, C/Sinesio Delgado 6, 28029 Madrid, Spain \\ ${ }^{\circ}$ Environmental Protection Agency of Emilia-Romagna, Via F. Rocchi, 19, Via Triachini, 17, 40138 Bologna, Italy \\ p Department of Hygiene, Epidemiology and Medical Statistics, Medical School, University of Athens, Mikras Asias 75, Goudi, GR-11527 Athens, Greece \\ ${ }^{\mathrm{q}}$ IMIM (Hospital del Mar Research Institute), C/Doctor Aiguader 88, 08003 Barcelona, Spain
}

\section{A R T I C L E I N F O}

\section{Article history:}

Received 29 July 2014

Accepted 17 November 2014

Available online 22 November 2014

\section{Keywords:}

Mortality

Hospital admissions

Particulate matter

Species

Chemical constituent

\begin{abstract}
A B S T R A C T
Background: Few recent studies examined acute effects on health of individual chemical species in the particulate matter (PM) mixture, and most of them have been conducted in North America. Studies in Southern Europe are scarce. The aim of this study is to examine the relationship between particulate matter constituents and daily hospital admissions and mortality in five cities in Southern Europe.

Methods: The study included five cities in Southern Europe, three cities in Spain: Barcelona (2003-2010), Madrid (2007-2008) and Huelva (2003-2010); and two cities in Italy: Rome (2005-2007) and Bologna (2011-2013). A case-crossover design was used to link cardiovascular and respiratory hospital admissions and total, cardiovascular and respiratory mortality with a pre-defined list of $16 \mathrm{PM}_{10}$ and $\mathrm{PM}_{2.5}$ constituents. Lags 0 to 2 were examined. City-specific results were combined by random-effects meta-analysis.

Results: Most of the elements studied, namely EC, $\mathrm{SO}_{4}^{2-}, \mathrm{SiO}_{2}, \mathrm{Ca}, \mathrm{Fe}, \mathrm{Zn}, \mathrm{Cu}, \mathrm{Ti}, \mathrm{Mn}, \mathrm{V}$ and Ni, showed increased percent changes in cardiovascular and/or respiratory hospitalizations, mainly at lags 0 and 1 . The percent increase by one interquartile range (IQR) change ranged from $0.69 \%$ to 3.29\%. After adjustment for total PM levels, only associations for $\mathrm{Mn}, \mathrm{Zn}$ and $\mathrm{Ni}$ remained significant. For mortality, although positive associations were
\end{abstract}

\footnotetext{
* Corresponding author at: Centre for Research in Environmental Epidemiology (CREAL), Doctor Aiguader 88, 08003 Barcelona, Spain.

E-mail address: xbasagana@creal.cat (X. Basagaña).

1 Both authors contributed equally to this work.

2 MED-PARTICLES Study group. Italy: E. Alessandrini, P. Angelini, G. Berti, L. Bisanti, E. Cadum, M. Catrambone, M. Chiusolo, M. Davoli, F. de' Donato,M. Demaria, M. Gandini, M. Grosa, A.

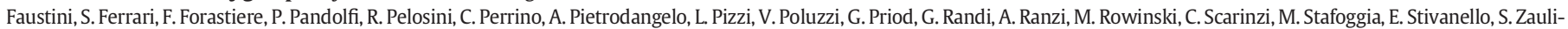

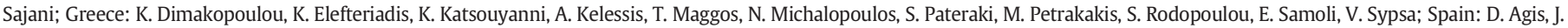

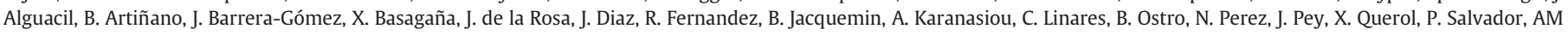
Sanchez, J. Sunyer, A. Tobias; France: M. Bidondo, C. Declercq, A. Le Tertre, P. Lozano, S. Medina, L. Pascal, and M. Pascal.
} 
identified (Fe and Ti for total mortality; $\mathrm{EC}$ and $\mathrm{Mg}$ for cardiovascular mortality; and $\mathrm{NO}_{3}^{-}$for respiratory mortality) the patterns were less clear.

Conclusions: The associations found in this study reflect that several PM constituents, originating from different sources, may drive previously reported results between PM and hospital admissions in the Mediterranean area.

(c) 2014 Elsevier Ltd. All rights reserved.

\section{Introduction}

Dozens of studies link increases in daily particulate matter (PM) levels to increases in mortality and hospital admissions (Brook et al., 2010; Brunekreef and Holgate, 2002), some in the Mediterranean area (Samoli et al., 2013; Stafoggia et al., 2013). However, particulate matter is a location- and season-dependent complex mixture of different components with potentially different toxicity. Several recent investigations have also examined the relationship between concentrations of individual chemical species and mortality or hospital admissions (Bell et al., 2009, 2014; Burnett et al., 2000; Franklin et al., 2008; Ito et al., 2011; Lall et al., 2011; Levy et al., 2012; Lippmann et al., 2006; Mar et al., 2000; Ostro et al., 2007, 2010, 2011; Peng et al., 2009; Sarnat et al., 2008; Son et al., 2012; Zanobetti et al., 2009; Zhou et al., 2011). Most of these studies were conducted in North America, while studies in other parts of the world, where chemical composition may be different, are still limited. In Europe, such studies are scarce and only included one city Ostro et al., 2011; Andersen et al., 2007; Atkinson et al., 2010. While it seems that some elements such as elemental carbon, nickel, and silicon are among the components most commonly associated with adverse health, the main conclusion derived from existing studies is that there is no sufficient evidence to identify the constituents more closely related to health outcomes (Environmental Protection Agency, 2009; Rohr and Wyzga, 2012; WHO (World Health Organization), 2013).

In this study, we examine the relationship between PM constituents and hospitalizations and mortality in five cities in Southern Europe, a region characterized by high vehicle and population densities, a high proportion of diesel cars, high sea traffic and peculiar meteorology with intense solar radiation, low precipitation and stagnation of regional air masses. These patterns confer to PM distinctive grain size and chemical patterns that are characterized by an important fraction of coarse (2.5$10 \mu \mathrm{m}$ ) PM into $\mathrm{PM}_{10}$ and relatively high proportions of mineral (anthropogenic and natural) dust and sulfate (Querol et al., 2009).

\section{Methods}

\subsection{Study population and data}

This study, within the context of the MED-PARTICLES project, included five cities, three in Spain (Barcelona, Madrid and Huelva) and two in Italy (Rome and Bologna) (Fig. A.1). City characteristics are provided in the Appendix. The overall period of study was from January 2003 to April 2013, although the different cities contributed to different periods according to data availability. Daily mortality counts for all nonexternal causes [International Classification of Diseases, 9th Revision (ICD-9) codes 001-799; 10th revision (ICD-10) codes A00-R99] (WHO (World Health Organization), 1999), for cardiovascular causes (ICD-9 codes 390-459, ICD-10 codes I00-I99) and for respiratory causes (ICD-9 codes 460-519, ICD10 codes J00-J99) were collected for all cities using death registries. Daily counts of emergency hospital admissions were collected from the national or regional health information systems. Repeated hospitalizations within 28 days since the previous one and with the same primary diagnosis were eliminated. Cardiovascular and respiratory hospitalizations were defined on the basis of the primary discharge diagnosis using the same ICD codes defined above. Since data were anonymous and collected as daily counts and the analysis was conducted by a public health institute, there was no need for informed consent and approval by an institutional review board.
$\mathrm{PM}_{10}$ and $\mathrm{PM}_{2.5}$ data for speciation analysis were available from a single station in each city. Madrid's station was urban while all other were urban background stations. More details about the stations are provided in the Appendix. $\mathrm{PM}_{2.5}$ data were not available for Rome while $\mathrm{PM}_{10}$ data were not available for Bologna. The period and frequency of sampling is shown in Table 1 . The specific methods used to measure the elements are described in the Appendix.

Only 16 pre-specified PM constituents were included in the association analyses: total carbon (TC), elemental carbon (EC), organic carbon (OC), sulfate $\left(\mathrm{SO}_{4}^{2-}\right)$, nitrate $\left(\mathrm{NO}_{3}^{-}\right)$, silica $\left(\mathrm{SiO}_{2}\right)$ (calculated as 3 times the alumina concentration in the Spanish cities), calcium (Ca), iron $(\mathrm{Fe})$, potassium $(\mathrm{K})$, magnesium $(\mathrm{Mg})$, zinc $(\mathrm{Zn})$, copper $(\mathrm{Cu})$, titanium (Ti), manganese ( $\mathrm{Mn})$, vanadium $(\mathrm{V})$ and nickel $(\mathrm{Ni})$. The list of 16 species was based on their detectability in the included cities and on a review of the literature linking PM constituents and health. If one of the above constituents had more than $20 \%$ of values missing or below the limit of detection or quantification in a certain city, the city was excluded from the analysis of that particular constituent. Otherwise, nondetectable values were replaced by half the limit of detection.

Daily average temperature and bank holidays were collected for each city. Information on influenza epidemics was obtained from hospital admission records. The collection of environmental and health data was performed by each partner and each one had its own quality control procedures, described in detail in the project website (www.epidemiologia.lazio.it/medparticles/ index.php/en/). They included the use of international reference materials as test samples, and calculation of mass balances between the PM mass and the addition of all the components analyzed.

\subsection{Study design and data analysis}

In cities with daily data, we used a time-stratified case-crossover study design (Levy et al., 2001), according to which all days from the same year, month and day of the week were grouped in the same stratum. In cities without daily data, a simplified version of the casecrossover approach was adopted: strata were composed of days from the same year and month, and days of the week were modeled separately with indicator variables (Ostro et al., 2011). Since the case-crossover analysis conducts comparisons within strata, seasonal and long-term effects are eliminated and they do not confound the results. Analyses were performed using conditional Poisson regression (Whitaker et al., 2006) and were further adjusted for holidays (different categories for isolated holidays, Christmas and Easter, and periods surrounding Christmas and Easter), summer population decrease (one indicator variable for the 2week period around 15 August and another for the remaining days between July 16th and August 31st), influenza epidemics, and temperature. To account for non-linearity and for the different lag structures of cold and hot temperatures, we included two separate spline terms for temperature, one for the cold period (temperatures below the annual median) using the average temperature for lags 1-6 and 2 degrees of freedom, and another for the warm period using average temperature for lags 0-1 and 3 degrees of freedom (Stafoggia et al., 2013).

All analyses were conducted separately for each city, and results were combined using random-effects meta-analysis. Lags 0,1 and 2 of the effect of each pollutant were examined in different models, as models accounting for cumulative lags could not be built in cities without daily data. In cities without daily exposure data, models for different lags are based on non-overlapping sets of mortality days. For example, with PM data collected on time $t$, lag 0 analyses link these data to 
Table 1

Data availability and summary of daily deaths and hospital admissions by city.

\begin{tabular}{|c|c|c|c|c|c|c|c|c|}
\hline \multirow[t]{2}{*}{ City } & \multirow[t]{2}{*}{ Date beginning-date end } & \multirow[t]{2}{*}{$\begin{array}{l}\text { Number } \\
\text { of days }\end{array}$} & \multirow[t]{2}{*}{$\begin{array}{l}\text { Frequency of } \\
\text { sampling }\end{array}$} & \multicolumn{2}{|c|}{$\begin{array}{l}\text { Daily admissions (mean } \pm \text { standard } \\
\text { deviation) }\end{array}$} & \multicolumn{3}{|c|}{ Daily deaths (mean \pm standard deviation) } \\
\hline & & & & Cardiovascular & Respiratory & Total & Cardiovascular & Respiratory \\
\hline Barcelona & 2003/01/01-2010/12/31 & 736 & Twice a week & $55.5 \pm 10.6$ & $55.1 \pm 19.4$ & $41.5 \pm 8.6$ & $13.0 \pm 4.1$ & $4.4 \pm 2.6$ \\
\hline Madrid & $2007 / 01 / 01-2008 / 02 / 29$ & 104 & Twice a week & $127.6 \pm 30.3$ & $142.2 \pm 45.7$ & $72.1 \pm 11.0$ & $21.7 \pm 5.0$ & $12.2 \pm 4.7$ \\
\hline Huelva & 2003/01/01-2010/12/31 & 406 & Once a week & $1.8 \pm 2.3$ & $0.9 \pm 1.2$ & $2.9 \pm 1.7$ & $1.0 \pm 1.0$ & $0.3 \pm 0.6$ \\
\hline Roma & 2005/01/01-2007/12/31 & 1059 & Daily & $81.9 \pm 18.7$ & $35.5 \pm 11.3$ & $57.0 \pm 10.5$ & $23.5 \pm 6.3$ & $3.5 \pm 2.2$ \\
\hline Bologna & $2011 / 11 / 15-2013 / 02 / 28$ & 472 & Daily & $16.8 \pm 4.6$ & $9.7 \pm 3.7$ & $12.2 \pm 3.7$ & - & - \\
\hline
\end{tabular}

mortality on day $t$, lag 1 analyses link them to mortality on day $t+1$ and lag 2 analyses link them to mortality on day $t+2$ (Ostro et al., 2011). Results are reported for an interquartile range (IQR) increase in pollutant concentrations.

In order to account for potential confounding for total PM levels, while accounting for the fact that PM constituents are components of $\mathrm{PM}$, we applied the recently proposed constituent residual method (Mostofsky et al., 2012). First, a linear regression model for the constituent as a function of total PM levels was fitted. Then, the residuals for this model, which represent the variation in constituent levels independent of PM, were included as an explanatory variable in the casecrossover model, along with total PM levels. The coefficient for the residuals represents the effect of the constituent while holding PM constant, i.e. the independent contribution of the constituent; and the PM coefficient represents the independent effect of total PM.

\section{Results}

Table 1 summarizes the daily number cardiovascular and respiratory hospital admissions and of deaths by natural, cardiovascular and respiratory causes in the five participating cities. Madrid, Rome and Barcelona are large cities with a high number of events, while Bologna and Huelva had lower numbers. Rome and Barcelona were the cities contributing most days to the analyses for $\mathrm{PM}_{10}$ and $\mathrm{PM}_{2.5}$, respectively.

The concentrations of $\mathrm{PM}_{10}$ and $\mathrm{PM}_{2.5}$ and of their selected constituents in the five cities are summarized in Table 2. The highest $\mathrm{PM}_{10}$ levels were observed for Barcelona and Madrid, with levels above $40 \mu \mathrm{g} / \mathrm{m}^{3}$, while Huelva and Rome showed levels between 30 and $35 \mu \mathrm{g} / \mathrm{m}^{3}$. In terms of $\mathrm{PM}_{2.5}$, the highest levels were found in Barcelona and Bologna, with values above $25 \mu \mathrm{g} / \mathrm{m}^{3}$, while Madrid and Huelva had values around $20 \mu \mathrm{g} / \mathrm{m}^{3}$. The selected species represented between $51 \%$ and $65 \%$ of the total PM levels depending on the city and fraction. TC, $\mathrm{SO}_{4}^{2-}, \mathrm{NO}_{3}^{-}, \mathrm{SiO}_{2}$ and Ca were among the species with the highest contribution in terms of mass, while the other species had much smaller contributions that did not exceed $4 \%$ of the mass in any city. Correlations between species and total PM are described in Tables A.1a-e.

Fig. 1 shows the associations between total $\mathrm{PM}_{10}$ and each $\mathrm{PM}_{10}$ component and cardiovascular and respiratory admissions, while Fig. 2 shows the corresponding results for $\mathrm{PM}_{2.5}$. Both total $\mathrm{PM}_{10}$ and $\mathrm{PM}_{2.5}$ were associated with cardiovascular admissions at lag 0 and with respiratory admissions at lags 1 and 2. For cardiovascular admissions, we observed increased percent changes for $\mathrm{Ca}, \mathrm{Fe}, \mathrm{Zn}, \mathrm{Cu}$, Ti and $\mathrm{Mn}$ from $\mathrm{PM}_{10}$. For $\mathrm{PM}_{2.5}$, we found increased percent changes for EC, $\mathrm{SO}_{4}^{2-}$ and $\mathrm{Mn}$. For respiratory admissions, we found increased percent changes for $\mathrm{SO}_{4}^{2-}, \mathrm{SiO}_{2}, \mathrm{Zn}, \mathrm{V}$ and $\mathrm{Ni}$ for $\mathrm{PM}_{10}$; while for $\mathrm{PM}_{2.5}$, increased percent changes were found for $\mathrm{EC}, \mathrm{Fe}, \mathrm{Zn}, \mathrm{V}$ and Ni. While most of the effects on cardiovascular hospitalizations were observed at lag 0 , the pattern was less clear for respiratory admissions where we found effects at lags 0,1 and 2. Results from $\mathrm{PM}_{10}$ and $\mathrm{PM}_{2.5}$ are not directly comparable, as they did not include the same cities. A comparison between the $\mathrm{PM}_{10}$ and $\mathrm{PM}_{2.5}$ results in cities that measured both fractions is shown in Figs. A.2 and A.3. For cardiovascular admissions, associations tended to be stronger for $\mathrm{PM}_{10}$, with the notable exception of EC. Patterns were less obvious for respiratory admissions.

Most of the increased percent changes were around $1 \%$ or $2 \%$ increase for one IQR increase in pollutant levels, reaching almost $3 \%$ for EC from $\mathrm{PM}_{2.5}$ for cardiovascular admissions and for $\mathrm{EC}$ and $\mathrm{Ni}$ from $\mathrm{PM}_{2.5}$ for respiratory admissions. The numeric results for all elements are shown in Table A.2. When adjusting for total PM levels using the constituent residual method, only $\mathrm{Mn}$ and $\mathrm{Zn}$ from $\mathrm{PM}_{10}$ for $\mathrm{CV}$

Table 2

Description (mean \pm standard deviation) of PM species ${ }^{\mathrm{a}}$ levels $\left(\mu \mathrm{g} / \mathrm{m}^{3}\right)$ by city.

\begin{tabular}{|c|c|c|c|c|c|c|c|c|c|c|}
\hline & \multicolumn{2}{|l|}{$\begin{array}{l}\text { Barcelona } \\
(2003-2010)\end{array}$} & \multicolumn{2}{|l|}{$\begin{array}{l}\text { Madrid } \\
(2007-2008)\end{array}$} & \multicolumn{2}{|l|}{$\begin{array}{l}\text { Huelva } \\
(2003-2010)\end{array}$} & \multirow{2}{*}{$\begin{array}{l}\text { Rome } \\
(2005-2007) \\
\mathrm{PM}_{10}\end{array}$} & \multirow{2}{*}{$\begin{array}{l}\begin{array}{l}\text { Bologna } \\
(2011-2013)\end{array} \\
\mathrm{PM}_{2.5}\end{array}$} & \multicolumn{2}{|c|}{ Common IQR } \\
\hline & $\mathrm{PM}_{10}$ & $\mathrm{PM}_{2.5}$ & $\mathrm{PM}_{10}$ & $\mathrm{PM}_{2.5}$ & $\mathrm{PM}_{10}$ & $\mathrm{PM}_{2.5}$ & & & $\mathrm{PM}_{10}$ & $\mathrm{PM}_{2.5}$ \\
\hline Total PM & $40.3 \pm 17.4$ & $26.3 \pm 12.2$ & $41.5 \pm 19.5$ & $20.7 \pm 9.2$ & $35.2 \pm 15.2$ & $20.8 \pm 10.7$ & $30.1 \pm 12.6$ & $27.6 \pm 19.5$ & 19.6 & 16.0 \\
\hline Total carbon & $6.9 \pm 3.7$ & $4.9 \pm 2.6$ & $10.4 \pm 5.6$ & $7.6 \pm 3.9$ & $5.4 \pm 3.4$ & $3.9 \pm 2.3$ & $10.6 \pm 5.2$ & $6.7 \pm 4.7$ & 5.2 & 3.8 \\
\hline $\mathrm{OC}$ & $3.3 \pm 1.8$ & $2.9 \pm 1.8$ & na & $6.0 \pm 2.7$ & na & na & $8.6 \pm 4.2$ & $5.1 \pm 3.9$ & 3.4 & 3.0 \\
\hline $\mathrm{EC}$ & $1.8 \pm 1.2$ & $1.5 \pm 1.0$ & na & $3.5 \pm 1.5$ & na & na & $2.2 \pm 1.3$ & $1.6 \pm 1.0$ & 1.4 & 1.1 \\
\hline $\mathrm{SO}_{4}^{2-}$ & $3.8 \pm 2.6$ & $3.4 \pm 2.3$ & $3.2 \pm 1.4$ & $2.4 \pm 1.1$ & $3.8 \pm 3.2$ & $3.3 \pm 2.7$ & $3.4 \pm 2.0$ & $2.4 \pm 1.6$ & 2.7 & 2.3 \\
\hline $\mathrm{NO}_{3}^{-}$ & $4.3 \pm 3.5$ & $2.4 \pm 3.2$ & $2.5 \pm 2.1$ & $1.5 \pm 1.7$ & $2.7 \pm 1.8$ & $1.2 \pm 1.2$ & $2.1 \pm 1.4$ & $5.1 \pm 7.9$ & 2.2 & 3.0 \\
\hline $\mathrm{SiO}_{2}$ & $3.8 \pm 3.6$ & $1.4 \pm 1.8$ & $2.2 \pm 1.8$ & $1.0 \pm 0.8$ & $4.9 \pm 4.4$ & $1.4 \pm 2.0$ & $1.0 \pm 0.9$ & nd & 2.7 & 1.1 \\
\hline $\mathrm{Ca}$ & $2.13 \pm 1.64$ & $0.60 \pm 0.62$ & $2.10 \pm 1.35$ & $0.26 \pm 0.16$ & $1.16 \pm 0.94$ & $0.33 \pm 0.52$ & $1.29 \pm 0.68$ & $0.10 \pm 0.06$ & 1.32 & 0.27 \\
\hline $\mathrm{Fe}$ & $0.86 \pm 0.54$ & $0.28 \pm 0.21$ & $1.67 \pm 0.87$ & $0.20 \pm 0.15$ & $0.66 \pm 0.52$ & $0.18 \pm 0.20$ & $0.46 \pm 0.26$ & $0.11 \pm 0.07$ & 0.63 & 0.18 \\
\hline K & $0.38 \pm 0.29$ & $0.20 \pm 0.23$ & $0.33 \pm 0.22$ & $0.20 \pm 0.41$ & $0.41 \pm 0.30$ & $0.21 \pm 0.20$ & $0.39 \pm 0.32$ & $0.18 \pm 0.30$ & 0.26 & 0.15 \\
\hline $\mathrm{Mg}$ & $0.279 \pm 0.165$ & $0.082 \pm 0.072$ & $0.225 \pm 0.150$ & $0.083 \pm 0.084$ & $0.295 \pm 0.193$ & $0.084 \pm 0.093$ & $0.095 \pm 0.098$ & nd & 0.153 & 0.069 \\
\hline $\mathrm{Zn}$ & $0.085 \pm 0.080$ & $0.059 \pm 0.068$ & $0.059 \pm 0.044$ & $0.050 \pm 0.026$ & $0.049 \pm 0.074$ & $0.045 \pm 0.084$ & $0.037 \pm 0.035$ & nd & 0.047 & 0.039 \\
\hline $\mathrm{Cu}$ & $0.056 \pm 0.051$ & $0.027 \pm 0.036$ & $0.113 \pm 0.069$ & $0.019 \pm 0.010$ & $0.047 \pm 0.078$ & $0.029 \pm 0.033$ & $0.040 \pm 0.020$ & nd & 0.051 & 0.021 \\
\hline $\mathrm{Ti}$ & $0.040 \pm 0.033$ & $0.014 \pm 0.013$ & $0.040 \pm 0.031$ & $0.008 \pm 0.014$ & $0.056 \pm 0.084$ & $0.020 \pm 0.039$ & $0.021 \pm 0.023$ & nd & 0.030 & 0.010 \\
\hline Mn & $0.018 \pm 0.011$ & $0.009 \pm 0.006$ & $0.020 \pm 0.011$ & $0.005 \pm 0.003$ & $0.013 \pm 0.024$ & $0.004 \pm 0.004$ & $0.012 \pm 0.008$ & nd & 0.011 & 0.004 \\
\hline V & $0.010 \pm 0.007$ & $0.008 \pm 0.006$ & $0.002 \pm 0.001$ & $0.001 \pm 0.001$ & $0.005 \pm 0.004$ & $0.004 \pm 0.003$ & $0.006 \pm 0.004$ & nd & 0.005 & 0.004 \\
\hline $\mathrm{Ni}$ & $0.005 \pm 0.003$ & $0.004 \pm 0.003$ & $0.002 \pm 0.001$ & $0.004 \pm 0.003$ & $0.003 \pm 0.003$ & $0.002 \pm 0.003$ & $0.005 \pm 0.003$ & nd & 0.003 & 0.004 \\
\hline
\end{tabular}

na: not available.

nd: non-detectable.

a Ordered by $\mathrm{PM}_{10}$ mass contribution when pooling all cities. 


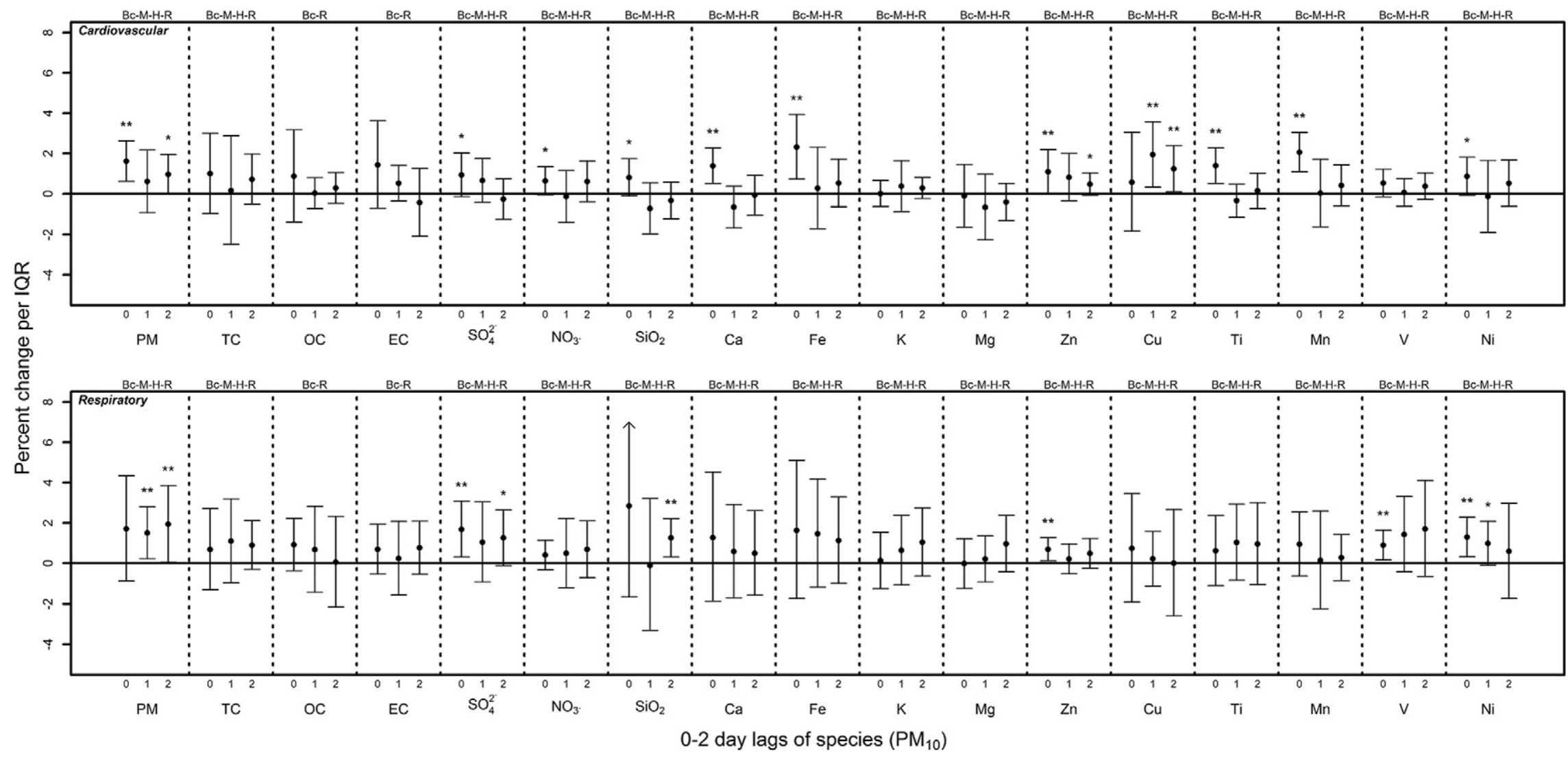

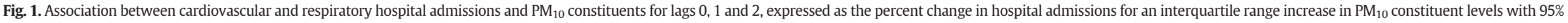

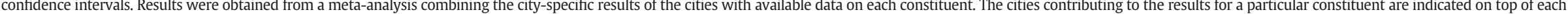
graph (Bc: Barcelona, M: Madrid, H: Huelva, R: Rome). $\left(^{*}\right)$ indicates a p-value $<0.10$, while $\left.{ }^{* *}\right)$ indicates a p-value $<0.05$. 


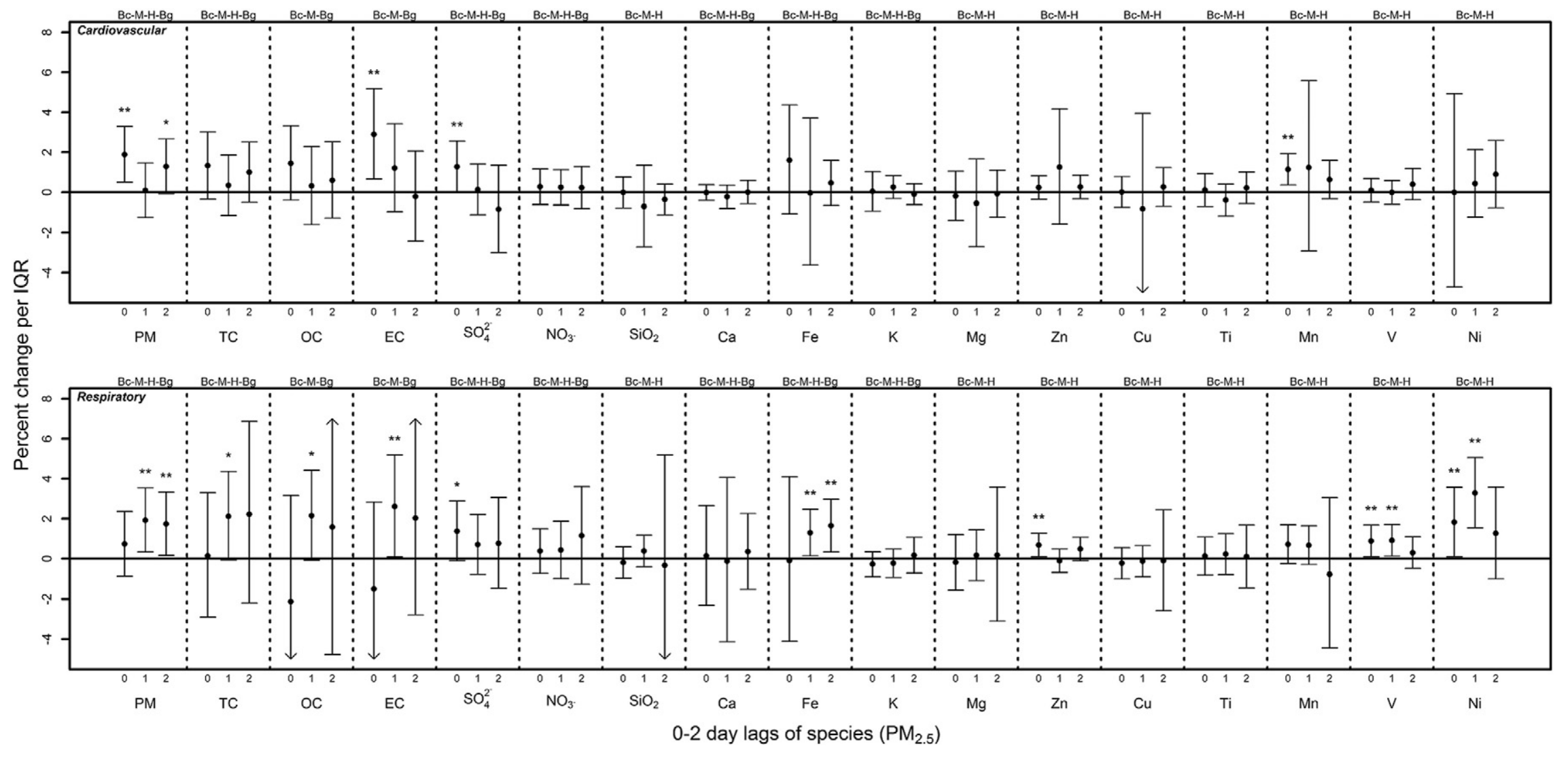

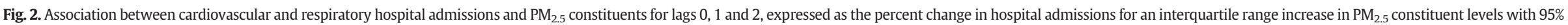

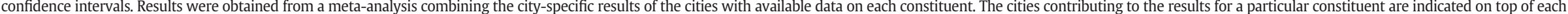
graph (Bc: Barcelona, M: Madrid, H: Huelva, Bg: Bologna). $\left({ }^{*}\right)$ indicates a p-value $<0.10$, while $\left({ }^{* *}\right)$ indicate a p-value $<0.05$. 
admissions and only $\mathrm{Ni}\left(\mathrm{PM}_{10}\right)$ and $\mathrm{Ni}$ and $\mathrm{Zn}\left(\mathrm{PM}_{2.5}\right)$ for respiratory admissions had 95\% confidence intervals not including one and remained with similar magnitude (Table A.4).

We found no increased percent changes in daily mortality in relation to total $\mathrm{PM}_{10}$ or $\mathrm{PM}_{2.5}$ (Figs. A.4 and A.5). In contrast, when the analysis was performed using complete time series (i.e. using daily data instead of restricting the analyses to days with data on PM species), significant associations with total PM were found (Samoli et al., 2013). We found increased percent changes in mortality for TC, Fe, $\mathrm{K}$ and Ti from $\mathrm{PM}_{10}$ and for $\mathrm{SiO}_{2}$ from $\mathrm{PM}_{2.5}$ (Figs. A.4 and A.5). For cardiovascular mortality, increased percent changes were found for $\mathrm{EC}$ from $\mathrm{PM}_{10}$, and for $\mathrm{Mg}$ and $\mathrm{Mn}$ from $\mathrm{PM}_{2.5}$. For respiratory deaths, we found increased percent changes for EC and Ni from $\mathrm{PM}_{10}$ and sulfate from $\mathrm{PM}_{2.5}$. We also found some decreased percent changes ( $\mathrm{TC}, \mathrm{OC}$ and $\mathrm{NO}_{3}^{-}$for some models). The numerical results of the mortality analyses are presented in Table A.3. Most of the associations ranged from 1 to $2 \%$ change per one IQR increase, although for respiratory deaths, the effect of $\mathrm{SO}_{4}^{2-}$ from $\mathrm{PM}_{2.5}$ (lag 2) was 5.26\% (0.79-9.92) and the effect of EC from $\mathrm{PM}_{10}$ (lag 1) was 5.29\% (1.37-9.37).

When adjusting for total PM, few associations persisted: $\mathrm{SiO}_{2}$, Fe and Ti for total mortality; for cardiovascular mortality, EC and Mg persisted and $\mathrm{Ca}, \mathrm{SiO}_{2}$ and $\mathrm{Fe}$, showed increased percent changes only after adjusting for total PM; and for respiratory mortality, $\mathrm{SO}_{4}^{2-}$ persisted and $\mathrm{K}$ showed increased percent changes after adjustment (Table A.5).

The between-city variation in effects and the weight of each city for four selected analyses at lag 0 are illustrated in Fig. A.6. Rome and Barcelona were the cities contributing the most to the total effects.

\section{Discussion}

This study investigated the relationship between $\mathrm{PM}_{10}$ and $\mathrm{PM}_{2.5}$ constituents and hospital admissions and mortality in five South-European cities. Several individual PM components showed increased percent changes in hospital admissions and/or mortality. More consistent results were found for hospital admissions, which had increased power due to a greater frequency of the outcome. The highest effects were found for $\mathrm{EC}$ and $\mathrm{Ni}$ but many other species showed increased percent changes. For mortality, the highest effects were found for respiratory mortality and $\mathrm{EC}, \mathrm{Ni}$ and $\mathrm{SO}_{4}^{2-}$. A few other species showed increased percent changes in mortality, and a few of them showed decreased percent changes. Most commonly, increased percent changes were found for hospitalizations at lag 0 and for mortality at lag 1 .

The associations found in this study reflect that acute exposure to several PM constituents, originating from different sources, may play a role in the association between PM and health. This general conclusion is in agreement with other reports that reviewed the available evidence (Environmental Protection Agency, 2009; Rohr and Wyzga, 2012; WHO (World Health Organization), 2013). Most of the PM constituents for which we found positive associations are the ones that have been most commonly reported in the literature. Although several epidemiological studies have evaluated the role of specific PM components on health, our study contributes to the gap of knowledge on this topic in Europe (Ostro et al., 2011; Andersen et al., 2007; Atkinson et al., 2010) and in particular in the Mediterranean area.

Carbonaceous particles are emitted from burning fossil fuels and biomass, as well as from the oxidation of natural and anthropogenic volatile organic compounds (VOCs) and from bioaerosols. Total carbon, EC and $\mathrm{OC}$ in urban areas have been used as markers for traffic emissions, and EC is considered to be a good marker of diesel vehicle emissions. $\mathrm{OC}$ is made of a highly complex mixture of compounds from combustion and non-combustion, anthropogenic and natural, and primary and secondary compounds (Jimenez et al., 2009). EC levels in $\mathrm{PM}_{2.5}$ were between 1.5 and $3.5 \mu \mathrm{g} / \mathrm{m}^{3}$ in the studied cities, higher than those found in most cities in the US (average $0.7 \mu \mathrm{g} / \mathrm{m}^{3}$ with range 0.3-1.7) (Bell et al., 2009), and somewhat similar to those reported for Seoul (Korea) $\left(2.2 \mu \mathrm{g} / \mathrm{m}^{3}\right.$ ) (Son et al., 2012). We found consistent increased risks of mortality and hospitalizations associated with EC. Other epidemiological studies have found associations with EC with total (Zhou et al., 2011) and cardiovascular mortality (Ito et al., 2011; Mar et al., 2000; Ostro et al., 2007; Zhou et al., 2011) and other with cardiovascular (Bell et al., 2009; Ito et al., 2011; Levy et al., 2012) and respiratory admissions (Bell et al., 2009). In fact, and especially for cardiovascular outcomes, most of the studies on mortality or hospital admissions, the studies on systemic biomarkers and the few controlled human exposure studies report significant associations with either EC or OC (or both) (Rohr and Wyzga, 2012). Positive results have also been found for respiratory outcomes, but less consistently.

Toxicological studies have described several pathways responsible for adverse health outcomes produced by diesel engine emissions. One of the main mechanisms involves production of an inflammatory response mediated by the induction of oxidative stress and the release of pro-inflammatory cytokines, but other mechanisms include changes in the bioavailability of NO within the vascular system, migration of leukocytes into bronchial tissue and effects on the immune system (Grahame et al., 2014). This evidence suggests a deleterious effect of carbon-containing particles, although the WHO (World Health Organization ) (2012) stated that EC may not be a directly toxic PM component but may act as a carrier for a wide range of chemical compounds of varying toxicity, such as aromatic polycyclic hydrocarbons, organic acids, and metals. Some animal studies found associations between carbon particles and increased heart rate, reduced heart rate variability, increased blood pressure but no inflammatory response (WHO (World Health Organization), 2013). However, studies in humans have linked EC and OC to inflammatory biomarkers (Delfino et al., 2009), and it has been suggested that the oxidative stress and inflammation associated with carbon particles may be due to the semivolatile organic fraction on the carbon particle core (WHO (World Health Organization), 2013; Cassee et al., 2013).

We studied two secondary inorganic aerosol species, $\mathrm{NO}_{3}^{-}$and $\mathrm{SO}_{4}^{2-}$. We found increases in respiratory mortality and hospitalizations and in cardiovascular hospitalizations associated with $\mathrm{SO}_{4}^{2}$-. In the mortality literature, $\mathrm{SO}_{4}^{2-}$ has been linked to total and cardiovascular deaths (Burnett et al., 2000; Franklin et al., 2008; Ito et al., 2011; Ostro et al., 2011; Anderson et al., 2001), but respiratory effects of $\mathrm{SO}_{4}^{2-}$ have been reported when looking at hospital admissions (Sarnat et al., 2008; Atkinson et al., 2010). A review of all the available evidence for $\mathrm{SO}_{4}^{2-}$ reported mixed results (Rohr and Wyzga, 2012). It has been suggested that $\mathrm{SO}_{4}^{2-}$ may act as a marker for other harmful constituents from oil and coal combustion, and in addition it can increase the toxic effects of Fe by increasing its solubility (WHO (World Health Organization), 2013; Cassee et al., 2013). For $\mathrm{NO}_{3}^{-}$, we did not find consistent results and few studies have reported adverse effects (Rohr and Wyzga, 2012; WHO (World Health Organization), 2013). The available toxicological evidence does not support a causal association between $\mathrm{SO}_{4}^{2-}$ or $\mathrm{NO}_{3}^{-}$and health risk (Cassee et al., 2013).

We found health effects of several metals. In particular, we found effects for a set of metals composed by $\mathrm{SiO}_{2}, \mathrm{Ca}$, Fe and Ti that were highly correlated in all participating cities. In addition, we also increased percent changes for $\mathrm{K}, \mathrm{Mg}$ and $\mathrm{Mn}$, which were highly correlated with the previous set in some but not all the cities. Most of the previous metals have mineral origin and have been apportioned to road dust and mineral factors in Southern European cities (Ostro et al., 2011; Amato et al., 2009). The infrequent rainfall favors the accumulation of road dust in the roads, which is then resuspended by traffic, a phenomenon particularly relevant in the Mediterranean area (Karanasiou et al., 2014). In this area, road dust, apart from having substances emitted by vehicle exhaust and wear, contains a large fraction of mineral dust, coming, for example, from construction work (Ostro et al., 2011; Amato et al., 2009; Querol et al., 2004). A recent review included Si and K among the group of elements that have been most frequently associated with health effects, along with $\mathrm{Ni}$ and $\mathrm{V}$ (discussed in the next paragraph), and $\mathrm{Zn}$ and $\mathrm{Cu}$ (Rohr and Wyzga, 2012), for which we also detected 
increased percent changes in hospital admissions. However, a proper assessment of the results in the literature is difficult, as not all studies included the same elements. Although not included in the top list by the review, it is worth noting that, as in our study, several epidemiological studies have found effects for Fe (Burnett et al., 2000; Ostro et al., 2007, 2009, 2010; Cakmak et al., 2009), and Mn (Lall et al., 2011; Ostro et al., 2007; Zanobetti et al., 2009; Cakmak et al., 2009). There exists toxicological evidence for the deleterious effects of metals, but they are not believed to account for all the health effects of PM (WHO (World Health Organization), 2013). For example, Mn and Fe have been related to oxidative stress markers in exposed human epithelial cells, and $\mathrm{Cu}$ and $\mathrm{Zn}$ have been linked to decrease in spontaneous beat rate, vasoconstriction and vasodilatation (Lippmann et al., 2013; Zhang et al., 2009).

Apart from the metals mentioned above, we also found effects of $\mathrm{Ni}$ and $\mathrm{V}$ on respiratory admissions and of $\mathrm{Ni}$ on respiratory mortality. $\mathrm{Ni}$ and $V$ are typical markers for fuel oil combustion (Viana et al., 2008). $\mathrm{Ni}$ has been the metal most commonly linked with health effects, mainly for cardiovascular outcomes (WHO (World Health Organization), 2013). A few studies have also reported effects of Ni on respiratory outcomes (Bell et al., 2009, 2014; Cakmak et al., 2009). V has also been associated with cardiovascular and respiratory admissions (Bell et al., 2009, 2014; Lippmann et al., 2006). Multiple toxicological studies in animals have reported effects of $\mathrm{Ni}$, including acute changes in heart rate variability; delayed hypothermia, bradycardia and arrhythmogenesis; respiratory carcinoma induction; expression of several genes involved in oxidative stress response, inflammation, repair/remodeling and vascular function; and apoptosis of ovary cells and T cell hybridoma cells (Zhang et al., 2009). V can induce expression of genes involved in injury/inflammation and vascular function, and has been shown to produce adverse reactions in human airway epithelial cells (Zhang et al., 2009).

We attempted to separate the effect of PM constituents and total PM levels by using the constituent residual method. For hospital admissions, only results from $\mathrm{Mn}, \mathrm{Zn}$ and $\mathrm{Ni}$ were robust to adjustment for total PM. An assessment of the results in the literature regarding models adjusted for PM or models including more than one constituent is difficult, as not all studies fitted such models or included the same constituents. EC has been shown to be robust in multi-pollutant models and is suggested to have a stronger effect than total PM (Grahame et al., 2014). In our study, even though EC effects lost statistical significance, point estimates were only slightly reduced. Ni has also shown some robustness in multi-pollutant models in some studies (Rohr and Wyzga, 2012). When adjusting for total PM in the mortality analyses, associations remained significant in some models for $\mathrm{SiO}_{2}, \mathrm{Fe}, \mathrm{Ti}, \mathrm{EC}, \mathrm{Mg}$, $\mathrm{SO}_{4}^{2-}$ and some associations were only significant after adjustment for $\mathrm{PM}$, as it was the case for Ca and K. It is important to note, though, that PM mass was not associated with mortality in single pollutant models. We believe that this may be due to a lack of power, since an association for total PM was detected when using daily PM values (including days without speciation data) (Samoli et al., 2013). Therefore, our mortality analyses should be interpreted with caution.

The study of the health effects of PM components is hindered by the large number of elements present in the PM mixture and the correlations between them. In our study, we found 95\% confidence intervals not including 1 in $8.3 \%$ of the comparisons, a higher percentage than what would be expected by chance, and all but six associations were positive. Although this supports the likelihood of harmful effect of some PM constituents, chance associations can be expected. The fact that the components found in this study are the ones most commonly reported in the literature gives more confidence in our results. The correlation between PM constituents is also problematic. We found effects for different constituents that were highly correlated. In such instances, even if a single responsible pollutant exists, it is hard to single it out. Models with multiple constituents were not fitted to avoid collinearity.

Our study suffered from additional limitations. Data were available for a single monitoring station in each city and they might not be good representatives of all the population. This introduces Berkson-type measurement error, as is common in most time-series studies of air pollution, which leads to no or little bias but decreases statistical power (Mostofsky et al., 2012). The multiple components of PM have different spatial distributions, and how well outdoor levels reflect indoor levels also varies by component. This leads to different degrees of measurement error - and therefore, of power - for each of them, and this may influence which associations are detected (Mostofsky et al., 2012). The study is also limited in not having daily data for some cities. This may preclude an adequate correction for time trends, but also it prevented the use of models combining the effects of multiple lags. Finally, our data were heterogeneous in terms of years and PM fractions used in each city and this may introduce some extra uncertainty in the metaanalysis results. Rome, a city with important weight in the analysis, did not have $\mathrm{PM}_{2.5}$ data. It is interesting to note, though, that there was a moderate concordance in the results for $\mathrm{PM}_{10}$ and $\mathrm{PM}_{2.5}$ in cities with both fractions available.

A better understanding of which elements, and therefore which sources, are the most harmful for health is very important from the policy point of view. In order to confirm these results, future studies should develop specific studies with a stronger focus on PM speciation, with ad-hoc long term campaigns of daily data in several locations and using the same protocols for data collection. Future studies should also explore the role of combined effects of several PM constituents, as toxicological studies have provided some evidence on interactions (e.g. between $\mathrm{C}$ and $\mathrm{Fe}$, or between $\mathrm{Ni}$ and $\mathrm{V}$ ) and other interactive biological effects have been suggested (e.g. secondary inorganic components influencing the bioavailability of metals) (WHO (World Health Organization), 2013; Cassee et al., 2013; Zhang et al., 2009).

This study examined the effects of PM constituents on hospitalizations and mortality in five Southern European cities. Our study suggests that several PM constituents are associated with increases in daily hospitalizations and mortality. Such elements come from different sources and some of them are highly correlated and therefore it is difficult to attribute effects to a particular constituent. Studies with larger datasets and daily data are needed to confirm these results in the Southern Europe.

\section{Conflict of interest statement}

The authors have no conflicts of interest to disclose.

\section{Acknowledgments}

The research described in this article was conducted under the grant agreement European Commission, Environment LIFE10/IT/327. We thank the Instituto Nacional de Estadística and the Agència de Salut Pública de Barcelona for providing the mortality data, the Consorci Sanitari de Barcelona (Cat-Salut) for providing hospitalization data for Barcelona and the Agencia Estatal de Meteorologia (Ministerio de Agricultura, Alimentación y Medio Ambiente) for providing the weather data for Spain.

\section{Appendix A. Supplementary data}

Supplementary data to this article can be found online at http://dx. doi.org/10.1016/j.envint.2014.11.011.

\section{References}

Amato, F., Pandolfi, M., Viana, M., Querol, X., Alastuey, A., Moreno, T., 2009. Spatial and chemical patterns of PM10 in road dust deposited in urban environment. Atmos. Environ. 43, 1650-1659.

Andersen, Z.J., Wahlin, P., Raaschou-Nielsen, O., Scheike, T., Loft, S., 2007. Ambient particle source apportionment and daily hospital admissions among children and elderly in Copenhagen. J. Expo. Sci. Environ. Epidemiol. 17 (7), 625-636.

Anderson, H.R., Bremner, S.A., Atkinson, R.W., Harrison, R.M., Walters, S., 2001. Particulate matter and daily mortality and hospital admissions in the west midlands conurbation 
of the United Kingdom: associations with fine and coarse particles, black smoke and sulphate. Occup. Environ. Med. 58 (8), 504-510.

Atkinson, R.W., Fuller, G.W., Anderson, H.R., Harrison, R.M., Armstrong, B., 2010. Urban ambient particle metrics and health: a time-series analysis. Epidemiology 21 (4), 501-511.

Bell, M.L., Ebisu, K., Peng, R.D., Samet, J.M., Dominici, F., 2009. Hospital admissions and chemical composition of fine particle air pollution. Am. J. Respir. Crit. Care Med. 179 (12), 1115-1120.

Bell, M.L., Ebisu, K., Leaderer, B.P., Gent, J.F., Lee, H.J., Koutrakis, P., Wang, Y., Dominici, F., Peng, R.D., 2014. Associations of PM2.5 constituents and sources with hospital admissions: analysis of four counties in Connecticut and Massachusetts (USA) for persons $>/=65$ years of age. Environ. Health Perspect. 122 (2), 138-144.

Brook, R.D., Rajagopalan, S., Pope III, C.A., Brook, J.R., Bhatnagar, A., Diez-Roux, A.V., Holguin, F., Hong, Y., Luepker, R.V., Mittleman, M.A., Peters, A., Siscovick, D., Smith Jr., S.C., Whitsel, L., Kaufman, J.D., 2010. Particulate matter air pollution and cardiovascular disease: an update to the scientific statement from the American Heart Association. Circulation 121 (21), 2331-2378.

Brunekreef, B., Holgate, S.T., 2002. Air pollution and health. Lancet 360 (9341), 1233-1242.

Burnett, R.T., Brook, J., Dann, T., Delocla, C., Philips, O., Cakmak, S., Vincent, R., Goldberg, M.S., Krewski, D., 2000. Association between particulate- and gas-phase components of urban air pollution and daily mortality in eight Canadian cities. Inhal. Toxicol. 12 (Suppl. 4), 15-39.

Cakmak, S., Dales, R.E., Gultekin, T., Vidal, C.B., Farnendaz, M., Rubio, M.A., Oyola, P., 2009. Components of particulate air pollution and emergency department visits in Chile. Arch. Environ. Occup. Health 64 (3), 148-155.

Cassee, F.R., Heroux, M.E., Gerlofs-Nijland, M.E., Kelly, F.J., 2013. Particulate matter beyond mass: recent health evidence on the role of fractions, chemical constituents and sources of emission. Inhal. Toxicol. 25 (14), 802-812.

Delfino, R.J., Staimer, N., Tjoa, T., Gillen, D.L., Polidori, A., Arhami, M., Kleinman, M.T., Vaziri, N.D., Longhurst, J., Sioutas, C., 2009. Air pollution exposures and circulating biomarkers of effect in a susceptible population: clues to potential causal component mixtures and mechanisms. Environ. Health Perspect. 117 (8), 1232-1238.

Environmental Protection Agency, 2009. Integrated Science Assessment for Particulate Matter (Final Report). United States Environmental Protection Agency, Washington, DC.

Franklin, M., Koutrakis, P., Schwartz, J., 2008. The role of particle composition on the association between PM2.5 and mortality. Epidemiology 19 (5), 680-689.

Grahame, T.J., Klemm, R., Schlesinger, R.B., 2014. Public health and components of particulate matter: the changing assessment of black carbon. J. Air Waste Manag. Assoc. 64 (6), 620-660.

Ito, K., Mathes, R., Ross, Z., Nadas, A., Thurston, G., Matte, T., 2011. Fine particulate matter constituents associated with cardiovascular hospitalizations and mortality in New York City. Environ. Health Perspect. 119 (4), 467-473.

Jimenez, J.L., Canagaratna, M.R., Donahue, N.M., Prevot, A.S., Zhang, Q., Kroll, J.H., DeCarlo, P.F., Allan, J.D., Coe, H., Ng, N.L., Aiken, A.C., Docherty, K.S., Ulbrich, I.M., Grieshop, A.P. Robinson, A.L., Duplissy, J., Smith, J.D., Wilson, K.R., Lanz, V.A., Hueglin, C., Sun, Y.L., Tian, J., Laaksonen, A., Raatikainen, T., Rautiainen, J., Vaattovaara, P., Ehn, M., Kulmala, M., Tomlinson, J.M., Collins, D.R., Cubison, M.J., Dunlea, E.J., Huffman, J.A., Onasch, T.B., Alfarra, M.R., Williams, P.I., Bower, K., Kondo, Y., Schneider, J., Drewnick, F., Borrmann, S., Weimer, S., Demerjian, K., Salcedo, D., Cottrell, L., Griffin, R., Takami, A., Miyoshi, T., Hatakeyama, S., Shimono, A., Sun, J.Y., Zhang, Y.M., Dzepina, K., Kimmel, J.R., Sueper, D., Jayne, J.T., Herndon, S.C., Trimborn, A.M., Williams, L.R., Wood, E.C., Middlebrook, A.M., Kolb, C.E., Baltensperger, U., Worsnop, D.R., 2009. Evolution of organic aerosols in the atmosphere. Science 326 (5959), 1525-1529.

Karanasiou, A., Querol, X., Alastuey, A., Perez, N., Pey, J., Perrino, C., Berti, G., Gandini, M., Poluzzi, V., Ferrari, S., de la Rosa, J., Diaz, J., Pascal, M., Samoli, E., Kelesis, A., Sunyer, J., Alessandrini, E., Stafoggia, M., Forastiere, F., the Med Particles Study Group, 2014. Particulate matter and gaseous pollutants in the Mediterranean basin: results from the MED-PARTICLES project. Sci. Total Environ. 488-489, 279-315.

Lall, R., Ito, K., Thurston, G.D., 2011. Distributed lag analyses of daily hospital admissions and source-apportioned fine particle air pollution. Environ. Health Perspect. 119 (4), 455-460.

Levy, D., Lumley, T., Sheppard, L., Kaufman, J., Checkoway, H., 2001. Referent selection in case-crossover analyses of acute health effects of air pollution. Epidemiology 12 (2), 186-192.

Levy, J.I., Diez, D., Dou, Y., Barr, C.D., Dominici, F., 2012. A meta-analysis and multisite time-series analysis of the differential toxicity of major fine particulate matter constituents. Am. J. Epidemiol. 175 (11), 1091-1099.

Lippmann, M., Ito, K., Hwang, J.S., Maciejczyk, P., Chen, L.C., 2006. Cardiovascular effects of nickel in ambient air. Environ. Health Perspect. 114 (11), 1662-1669.

Lippmann, M., Chen, L.C., Gordon, T., Ito, K., Thurston, G.D., 2013. National Particle Component Toxicity (NPACT) Initiative: integrated epidemiologic and toxicologic studies of the health effects of particulate matter components. Res. Rep. Health Eff. Inst. 177, 5-13.

Mar, T.F., Norris, G.A., Koenig, J.Q., Larson, T.V., 2000. Associations between air pollution and mortality in Phoenix, 1995-1997. Environ. Health Perspect. 108 (4), 347-353.

Mostofsky, E., Schwartz, J., Coull, B.A., Koutrakis, P., Wellenius, G.A., Suh, H.H., Gold, D.R. Mittleman, M.A., 2012. Modeling the association between particle constituents of air pollution and health outcomes. Am. J. Epidemiol. 176 (4), 317-326.

Ostro, B., Feng, W.Y., Broadwin, R., Green, S., Lipsett, M., 2007. The effects of components of fine particulate air pollution on mortality in California: results from CALFINE. Environ. Health Perspect. 115 (1), 13-19.

Ostro, B., Roth, L., Malig, B., Marty, M., 2009. The effects of fine particle components on respiratory hospital admissions in children. Environ. Health Perspect. 117 (3), 475-480.

Ostro, B., Lipsett, M., Reynolds, P., Goldberg, D., Hertz, A., Garcia, C., Henderson, K.D., Bernstein, L., 2010. Long-term exposure to constituents of fine particulate air pollution and mortality: results from the California Teachers Study. Environ. Health Perspect. 118 (3), 363-369.

Ostro, B., Tobias, A., Querol, X., Alastuey, A., Amato, F., Pey, J., Perez, N., Sunyer, J., 2011. The effects of particulate matter sources on daily mortality: a case-crossover study of Barcelona, Spain. Environ. Health Perspect. 119 (12), 1781-1787.

Peng, R.D., Bell, M.L., Geyh, A.S., McDermott, A., Zeger, S.L., Samet, J.M., Dominici, F., 2009 Emergency admissions for cardiovascular and respiratory diseases and the chemical composition of fine particle air pollution. Environ. Health Perspect. 117 (6), 957-963.

Querol, X., Alastuey, A., Viana, M.M., Rodriguez, S., Artiñano, B., Salvador, P., Garcia do Santos, S., Fernandez Patier, R., Ruiz, C.R., de la Rosa, J., Sanchez de la Campa, A. Menendez, M., Gil, J.I., 2004. Speciation and origin of PM10 and PM2.5 in Spain. Aerosol Sci. 35, 1151-1172.

Querol, X., Alastuey, A., Pey, J., Cusack, M., Perez, N., Mihalopoulos, N., Theodosi, C., Gerasopoulos, E., Kubilay, N., Koçak, M., 2009. Variability in regional background aerosols within the Mediterranean. Atmos. Chem. Phys. 9, 4575-4591.

Rohr, A.C., Wyzga, R.E., 2012. Attributing health effects to individual particulate matter constituents. Atmos. Environ. 62, 130-152.

Samoli, E., Stafoggia, M., Rodopoulou, S., Ostro, B., Declercq, C., Alessandrini, E., Diaz, J. Karanasiou, A., Kelessis, A.G., Le Tertre, A., Pandolfi, P., Randi, G., Scarinzi, C., ZauliSajani, S., Katsouyanni, K., Forastiere, F., 2013. Associations between fine and coarse particles and mortality in Mediterranean cities: results from the MED-PARTICLES project. Environ. Health Perspect. 121 (8), 932-938.

Sarnat, J.A., Marmur, A., Klein, M., Kim, E., Russell, A.G., Sarnat, S.E., Mulholland, J.A., Hopke, P.K., Tolbert, P.E., 2008. Fine particle sources and cardiorespiratory morbidity: an application of chemical mass balance and factor analytical source-apportionment methods. Environ. Health Perspect. 116 (4), 459-466.

Son, J.Y., Lee, J.T., Kim, K.H., Jung, K., Bell, M.L., 2012. Characterization of fine particulate matter and associations between particulate chemical constituents and mortality in Seoul, Korea. Environ. Health Perspect. 120 (6), 872-878.

Stafoggia, M., Samoli, E., Alessandrini, E., Cadum, E., Ostro, B., Berti, G., Faustini, A., Jacquemin, B., Linares, C., Pascal, M., Randi, G., Ranzi, A., Stivanello, E., Forastiere, F., 2013. Short-term associations between fine and coarse particulate matter and hospitalizations in Southern Europe: results from the MED-PARTICLES project. Environ. Health Perspect. 121 (9), 1026-1033.

Viana, M., Kuhlbusch, T.A.J., Querol, X., Alastuey, A., Harrison, R.M., Hopke, P.K., Winiwarter, W., Vallius, M., Szidat, S., Prévôt, A.S.H., Hueglin, C., Bloemen, H., Wåhlin, P., Vecchi, R., Miranda, A.I., Kasper-Giebl, A., Maenhaut, W., Hitzenberger, R., 2008. Source apportionment of particulate matter in Europe: a review of methods and results. J. Aerosol Sci. 39 (10), 827-849.

Whitaker, H.J., Farrington, C.P., Spiessens, B., Musonda, P., 2006. Tutorial in biostatistics: the self-controlled case series method. Stat. Med. 25 (10), 1768-1797.

WHO (World Health Organization), 2013. Review of Evidence on Health Aspects of Air Pollution - REVIHAAP Project: Final Technical Report. WHO Regional Office for Europe, Bonn.

WHO (World Health Organization), 1999. International classification of diseases (ICD) Available, http://www.who.int/classifications/icd/en/ (accessed: 28 April 2014).

WHO (World Health Organization), 2012. Health effects of black carbon. Available, http:// www.euro.who.int/_data/assets/pdf_file/0004/162535/e96541.pdf (accessed 28 April 2014).

Zanobetti, A., Franklin, M., Koutrakis, P., Schwartz, J., 2009. Fine particulate air pollution and its components in association with cause-specific emergency admissions. Environ. Health $8,58$.

Zhang, Z., Chau, P.Y., Lai, H.K., Wong, C.M., 2009. A review of effects of particulate matterassociated nickel and vanadium species on cardiovascular and respiratory systems. Int. J. Environ. Health Res. 19 (3), 175-185.

Zhou, J., Ito, K., Lall, R., Lippmann, M., Thurston, G., 2011. Time-series analysis of mortality effects of fine particulate matter components in Detroit and Seattle. Environ. Health Perspect. 119 (4), 461-466. 